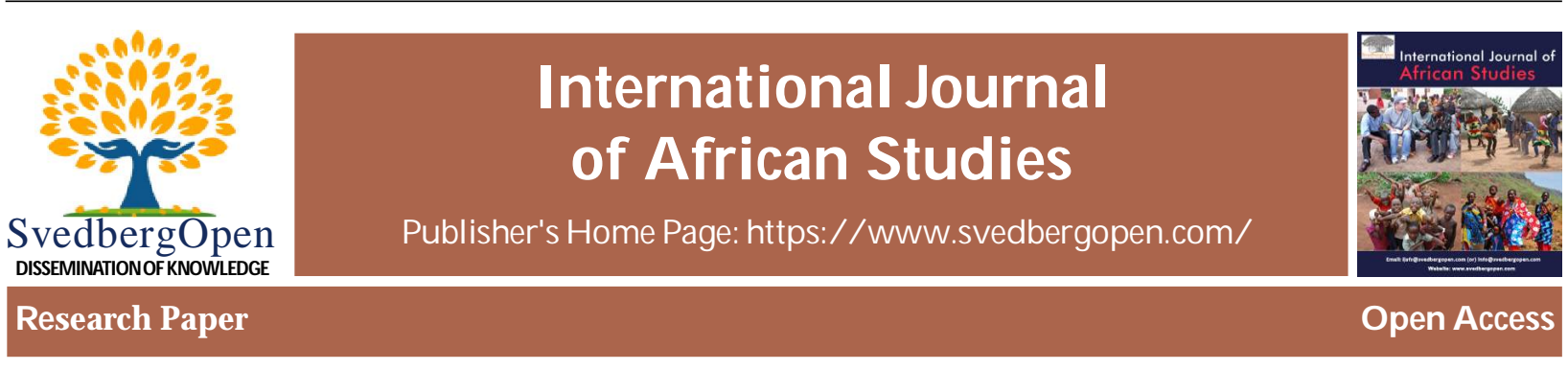

\title{
Sketching Whiteness in a Mestizo Nation
}

\author{
Natalia Santiesteban-Mosquera ${ }^{1 *}$ \\ ${ }^{1}$ Independent Researcher, Bogotá, Colombia. E-mail: nataliasantiestebanmosquera@gmail.com
}

\section{Article Info}

Volume 1, Issue 3, September 2021

Received : 12 February 2021

Accepted : 15 August 2021

Published : 05 September 2021

doi: 10.51483/IJAFRS.1.3.2021.31-40

\begin{abstract}
Epistemologically framed by Black Feminism, (auto) ethnography, the heuristic $I$ approach, and racial studies in Colombia, the present work centers the author's lived experience in the analysis of day-to-day school dynamics and the ways in which they (re)produce gendered racial discourses laying at the very foundation of the Colombian national project. The concurrence of biographic narrative and digital ethnogrpahy, highlights particular intersections of class, race, sexuality, ability, and gender, and ultimately brings forth notions of belonging, national identity, and ideal femininity.

Keywords: Gender, Race, Intersectionality, Catholicism, School, Ethnography, Colombia, Andes, National Project

(C) 2021 Natalia Santiesteban-Mosquera. This is an open access article under the CC BY license (https://creativecommons.org/licenses/by/4.0/), which permits unrestricted use, distribution, and reproduction in any medium, provided you give appropriate credit to the original author(s) and the source, provide a link to the Creative Commons license, and indicate if changes were made.
\end{abstract}

\section{Introduction}

This paper aims to delineate the flow of a common discourse that is rarely ever the subject of neither formal/academic, nor informal/everyday conversations and that therefore seems to escape criticism, especially in so called mestiza nations. Who claims whiteness in the land of the cosmic race? How do we define its limits? How does Colombian society project, construct, and enact whiteness? How do we establish hues and shades of white? How does this inform our subjectivities and identities? And, most importantly, how and where do we, as a nation, embody it?

Analytically centering my own lived experience as a black child in Colombian denominational (catholic) all-girls, private schools, and highlights the ways in which day-to-day dynamics in these particular environments privilege the (re)production of racial discourses that lay at the very foundation of the Colombian national project. Drawing upon my narrative, and a brief digital ethnographic experiment, I spot particular intersections of class, race, sexuality, ability, and gender, to explore the ways in which they inform notions of belonging, national identity, and ideal femininity.

Moreover, I interrogate the local construction(s) of whiteness primarily under the light of my biographic accounts. I question the influence of Catholicism in shaping racialized gender roles, as I use my subjective experience to reflect on a multidimensional idea of void as a condition of possibility for whiteness.

\section{Integral Catholicism and education in Colombian nation-state}

Before I go into the story, I need to underscore the relevance of Catholicism in our society. As of 2019, the country ranks seventh on the list of 10 most Catholic nations (Aleteia, 2019). Although the Colombian state was declared officially multicultural, multiethnic, and secular since 1991, the main national idiosyncrasy remains imbued in this particular set of

\footnotetext{
* Corresponding author: Natalia Santiesteban-Mosquera, Independent Researcher, Bogotá, Colombia.

E-mail: nataliasantiestebanmosquera@gmail.com
} 
religious discourses, values, and practices, instilled by the Spaniards in colonial era, and reaffirmed by the concordat of 1886.

In its first article, the said treaty (renewed in 1973) stipulates that "the state, in response to the traditional catholic feeling of the Colombian nation, considers Catholic Apostolic, Roman church as a fundamental element for common wellbeing and integral development of national community"' (Corte Suprema de Justicia de Colombia, 1973). The concordat grants the Catholic Church freedom to establish, organize, and direct educational institutions in every level and specialty. Furthermore, it acknowledges religious education as a right for Colombian families, and designates the C.A.R Church as the official leader of social assistance and development projects for vulnerable areas of the country (Corte Suprema de Justicia de Colombia, 1973).

On the other hand, the Colombian Political Constitution of 1991 not only underscores cultural, ethnic and religious diversity, but it also stresses religious freedom as a fundamental right. As a capital milestone in its history, the former officially proclaimed Nation of the Sacred Heart (Gutiérrez, 1994) ${ }^{2}$, replaces its consecration to the passion of JesusChrist, by the institution of laicism. In contrast with the former chart, the Constitution of 1991 refers to citizens as such, instead as of "souls". At the same time, it is this Constitution the one that brings race, ethnicity, culture and gender to the public realm, but moreover underscores the nation-state's obligation to protect the civil rights of so-called ethnic (Afro-Colombians and Indigenous), and sexually diverse populations.

This radical political displacement might have been expected to bring deeper and more noticeable social and cultural transformations. Nonetheless, according to historian Ricardo Arias, our officially secular nation can still be described as a global system in which every institution (civil state, school, medical and social assistance, etc.), as well as every collective or individual manifestation (politics, economy, culture, morals, arts, sciences, etc.) is determined by religiosity (Arias, 2000).

As opposed to the United States or Canada, enrolling in Catholic education in Colombia does not necessarily speak about the level of religious commitment or the particular moral project of an individual, or a family; since colonization, it became plainly a cultural custom. Starting in 1604, religious communities of Spanish origin established the most important educational centers in Colombia. By 1930, 50\% of all schools in the country were directed by religious congregations. Besides, there was not a clear distinction between official and private cadres because Catholic congregations intervened in most educational institutions (Helg, 1987).

Ultimately, the school, a crucial site for the (re)production of hegemonic discourses at the root of the national project, was inevitably imbued in Catholic, Euro-centric, patriarchal ideologies. The everyday reality of any religious school become then a privileged locus for the recreation and manifestation of a dominant normativity that transcends and challenges the democratic project proposed by the latest Constitution. Race, gender, sexuality and class dynamics are structurally shaped by religion and religion structurally informed education. This is where the heuristic power of my biographic narrative stems from.

\section{A good school, for a good (white-mestiza) girl}

In 1955, alumni of Salesian school Hijas de María Auxiliadora decided to collaborate in the evangelization and social development of neighborhood El Encanto, in west Bogotá. Both nuns and former students targeted the then vulnerable, impoverished western area of the city and decided to engage with its inhabitants mainly by means of charity and catechesis. Hijas de María Auxiliadora was the wealthier school of all the ones directed by the same religious community. It is also usual that each of the largest or most ancient religious companies run several schools in different class backgrounds. Margarita Bosco came to fill in the gap for a working class institution within the Salesian portfolio.

Following the tradition of an integral Catholicism, members of the wealthier school teamed-up to visit family homes and serve the ones in need, with the aim of shaping a community that was morally fit to foster a new religious institution, ruled by traditional catholic values, and especially designed to cater for less socially and economically privileged girls. Margarita Bosco was thus established as commercial-oriented, that is to say, it would profile its students as potential subordinate clerical employees through an education that centered accounting, typing and other related skills.

According to its official website, the school of Margarita Bosco was founded "under the eye of Virgin Mary", and "is sustained by sacramental life". It also "up brings Colombian women under human, Christian, and Salesian principles" as

\footnotetext{
Original version in Spanish: "El Estado, en atención al tradicional sentimiento católico de la Nación Colombiana, considera la Religión Católica, Apostólica y Romana como elemento fundamental del bien común y del desarrollo integral de la comunidad nacional."

2 Before 1991, Colombia's devotion to the Sacred Heart had been made official by state regulations abolished by the new Constitution.
} 
it "instills in its students values of joy, study and pity, in a familiar environment that advances personal integrity amongst girls (Colegio Margarita Bosco, 2019)"

And there I was...dépaysée ${ }^{3}$

In 1987, at the tender age of five, I had the (mis)fortune of being enrolled in the first grade of elementary school at Margarita Bosco. Pre-school years had already been challenging for both my mother and me, but we managed to succeed at defeating the aggressive racist bullying that got in our way since day one. This new school, however, was literally and figuratively a whole new level of terror. Just stepping foot on campus was scary for me because the everyday environment was different now in a way that seemed less safe.

Traditionally in Colombia, middle-class pre-schools and nurseries have operated in residential houses that are adapted to function as daycare and educational units. I knew what a regular campus looked like (my mother was a teacher in one of those) but the idea of school facility that I had experienced was closer to that of a home. In our country, a child will often have all of their education in the same institution, as opposed to Europe or the United States, where preschool, elementary, middle, and high-school function in different facilities. In Colombia, in fact, a person can graduate from the same place that schooled them since early childhood. I imagine for people who followed this pattern, the transition from kindergarten to the next level was different, perhaps not as abrupt as it was for someone like me.

While in kindergarten, we played at a small backyard of what would often be a house previously inhabited by a large, traditional, middle or middle-to-lower class Colombian family. Our classrooms would be literally regular bedrooms, full of toys, playfully decorated, and furnished with little, colorful chairs and desks. In some cases, the owners of the place would live in the facilities and for instance, share the kitchen or the porch with the pre-school. Physical space was considerably smaller and more intimate there. Margarita Bosco, conversely, had a real campus with, so to speak, real buildings. It was large enough to foster perhaps 500 students. The classrooms, the library, and the nun's residences were in the four-story building in the back, facing the tree tunnel and the courtyard. The auditorium and the chapel shared a hall that was adjacent to the classrooms.

I remember being struck by a painful feeling of emptiness every time I entered the place. As opposed to the kindergarten house, everything and everyone, from the doorman to my classmates, from the entrance gate to the classroom seemed to be taller and larger than me. There were not only more girls but also older ones. I guess I resented the fact that, under these circumstances, teachers were not as devoted to care as the pre-school ones. Nuns could eventually become bullies as well, and overall adult supervision did not seem adequate enough to keep young girls safe from one another. I was all alone in a campus full of mostly merciless girls my age, surprisingly nicer girls that were older and thus inaccessible, unpredictable nuns, and conveniently violence-blind teachers. Middle school and high school operated in the afternoon, as opposed to the elementary.

Elementary school started earlier and that impacted me as well. While in kindergarten I used to get up after sunrise, now I had to get ready when it was still dark and Bogotá was at its coldest. I do not remember thinking I was afraid of school but to this day I keep in my body a feeling of almost painful void, mixed to the exaggeration of every stimulus from the environment. The smell of ham and cheese in my lunchbox, the cobalt blue of my uniform, the air, the sun rays, everything would strike my senses with a strength magnified by fear. Vertigo was then the leitmotif of my mornings. I felt everything twirled inside me in perpetual nausea and I was so used to it that I never complaint. Having my humanity liquefied under shining light is what best describes this experience. Oddly enough, the city of Bogotá, where black people are historically minoritized, is celebrated in its official anthem as the "white star that shines on the Andes". I guess it was white and shiny enough to jeopardize my mere (black and opaque?) existence.

\section{“Antes, acá no se veían negros”4 (Rosero-Labbé, 1998): where did I belong?}

The whole upsetting, both within me and in the scene, reached its peak when I entered campus. As the only black girl in the entire elementary section, my presence itself disrupted an order, a tradition. Not only were black people a minority in the city, but also black girls in particular were not expected to attend a school like this one, regardless of its relatively

Dépaysé, dépaysée: disoriented, uprooted, disconnected from the motherland. I chose this term over the English one because the notion itself cannot be really translated. I discovered it during my college years, through the reading of Francophone Caribbean poets and philosophers such as Édouard Glissant, Aimé Césaire, Raphaël Confiant er Patrick Chamoiseau. Le dépaysement is a current trope in their literature and it vehicules the particular experience of displacement lived by the African Diaspora during, after, and as aresult of the Middle Passage. The legacy of Creole literature is the possibility of combating dépaysement through the art of writing.

English translation: "You would not see blacks here before", which is an often used expression to point out a perceived increase in black populations in the city. Originally taken from the title "Acá antes no se veían negros: Estrategias de inserción de migrantes del Pacífico colombiano en Bogotá", a book published in 1998, by Colombian scholar Claudia Mosquera Rosero-Labbé. 
low socio-economic status. In fact, the presence of Black people in Bogotá was generally not expected. It is true that "Colombia, following Brazil, accommodates the second largest Afro-descendant population in Latin America." (World Bank, 2005). However, it is not concentrated in the capital.

According to the census of 2005, Bogotá is the city with the smallest native black population and also the one with the highest rate of local black immigrants (Alcaldía Mayor de Bogotá, 2005). My parents, for instance, represent the latest. For afro-bogotanxs, or the ones born and raised in Bogotá, it is a common experience to face disbelief or derision when stating that, in fact, we are local. Questions like "but where are really you from?" or "why don't you speak with the typical coastal accent?" will often follow my assertion that I am originally from the capital. None of this would represent a problem of any sort—and most importantly, it would not impact our subjectivities- if our imagined foreignness were not inextricably racialized.

In his book, An Aqueous Territory: Sailor Geographies and New Granada's Transimperial Greater Caribbean World, historian Ernesto Bassi-Arévalo points out that, after its independence from Spain, Colombia was projected as an Andean-Atlantic nation, that is to say, one that delinked itself from a "Caribbean world perceived as threatening" and conversely strengthened its links to the North-Atlantic centers of civilization (Europe and the United States). Bassi refers to this process of disconnection as the "decaribbeanization of the [then] nascent republic". The author explains Colombian nation-making hegemonic narrative as follows:

"Instead of embracing the Caribbean Sea and Atlantic Ocean from New Granada's shores, it does so, mostly, from the perspective of the Andean capital of the nascent republic, where a group of enlightened nation makers envisioned a new Colombian nation that could shun the stigma of blackness, barbarism, and obscurantism associated with the Caribbean, and present itself to the world as white, civilized, and enlightened (...)Drawing on an Enlightenment education that characterized the tropical lowlands (the coast) and their population as backward, enlightened creoles developed an argument that stressed the civilizational possibilities the Andes offered. Politician-geographers, on the other hand, created and used cartographic and geographic representations of the nation to construct an image of Colombia as an Atlantic nation. Together, they made possible the decaribbeanization of the new republic and the creation of an Andean-Atlantic nation." (Bassi, 2016).

Within this decaribbeanizing project, the regionalization of race is not only one of the most salient vestiges of Spanish colonization, but also a determinant factor in the geopolitical issues of our nation since its beginnings. Colonizers -and the development project they centralized in this area- occupying the inlands (mainly he Andes), significantly undermining native communities, and relegating populations from African descent to the Pacific and Caribbean coasts, resulted in our current geographical division of race, that is to say, one that monopolizes care, wealth, and hope for a better future while condemning life on the coasts to abandonment and despair (Santiesteban Mosquera, 2017)

Naturally, my political awareness was far from its peek at the age of five. Not so naturally, the hostile gaze of the environment made me feel unwelcome. It was virtually impossible for me to know that my skin was seen as the major threat for Christianity, progress and decaribbeanization, but the scorn I experienced was not fed by theory. It could not have come from history lessons I have still not had. Instead it came from insults, mockery, and isolation. It came from the girl in my classroom throwing crashed moths at me. It stemmed from the silence of the teacher who refused to hear me ask for help in her art class. It came from the nun who mocked my complexion and my hairstyle in front of my peers, at the playground.

I never thought fear but my insides felt it. My skin felt it. My braided hair, always under the scrutiny of others, felt it. Just the sight of the tall, heavy black gate was intimidating to me. Even knowing he was everything but dangerous, I would find Don Pablito, the doorman, somehow threatening. He wasn't always rude, but not particularly sweet or welcoming either. He was loved by the children anyway. I probably loved him, too.

The black, heavy gate led directly to a tree tunnel. In the right mood, walking through it to the building at the bottom, where the classrooms were, would be sweet. Calm at least. In my state of spirit, however, it felt like the threat of vacuum. The depths of my fragile inner being mirrored the shadow of each and every tree. The pressing sensations of darkness and agitation haunted me through the corridor, making the walk burdensome, longer. My heart was usually pounding and I would most often be silent. I only spoke when I had to: to explain that my hair was not dirty wool, that my skin was not burnt, that my name was not "negra", or simply to comment on more interesting stuff, when the girl with what I always believed were rotten teeth wanted to chat and had not found anyone else.

I now understand scarcity might have been at the root of her tooth decay. It is plausible that her family could not afford dental care, that her mother's diet had lacked any essential mineral during pregnancy, or that there was not a culture of oral care at their home (which in Colombia is also related to poverty). It is also possible that the unfair 
coloration of her teeth was caused by bruising after an accident. In whatever manner, at the tender age of five, being an outcast, having her as my only (unchosen) company felt like misery. I was convinced that a smile was by far the prettiest, friendliest gesture someone could receive, but also that an acceptable smile should always be light, white. In my eyes, the only smile that was granted to me was corrupted. Somehow seeing my blackness once again mirrored in a "rotten" smile made me believed, once again, that I belonged to the cold, the ugly, the nothing, and the no-where.

To this day I am still unable to explain how I managed to function in such circumstances. I do not know how I was able to shift so abruptly from morning to afternoon. How could I just forget everything once I got home and simply live a different life? How did I manage to shift every day, from one spirit to another?

\section{You are (still) black, but American visa takes you anywhere}

Those were times of sharp contrasts in my inner world as in my surroundings. The oppression and ostracizing I experienced in the mornings would abruptly turn into liberation and sweet solitude once at home, every afternoon. At school, my brown skin, big slanted eyes, kinky hair, and beaded braids would also stand out amongst the lighter complexions, sometimes light eyes, and straight or wavy manes of my white-mestiza peers, the teachers, the nuns, the doorman, the Virgin Mary, Jesus Christ, the Saints, Mother Margarita Bosco and her son Don Juan, and every other human figure, living or inanimate.

At the same time, my cleanliness, well stocked lunch boxes, careful upbringing, outstanding academic performance, new toys, fashionable backpacks, fancy (American) toys and Disney-adorned stationery would violently contrast the scarcity of many of my classmates, most of whom were not black. While my family was relatively well off at that time, this did not save me from social exclusion. I was so young and puzzled by the situation, that being "richer" did not really have a meaning for me. At least not in first grade.

Change came to my life the moment I knew we were appointed to spend what was left of the year in the US, with my baby sister and my parents. I then felt free to tell my mom about all the suffering I had been enduring at school so far. I had never before said a word about that. She then went to the school and confronted the nuns and the teachers who, at their turn, conducted this sort of anti-bullying campaign that basically consisted of going to every classroom calling everybody out on their mistreatment of me.

I wish I could believe this gesture came from genuine awareness. I doubt anyone in charge would have responded this way if my mother had not shown she could afford the annual tuition paid in full for me and another student sponsored anonymously, who probably treated me as poorly as most of them. Apparently, both the announcement of my departure, and the calling out opened several eyes and softened many girls' hearts because months later, after my arrival from abroad, for the beginning of second grade, I met a substantially different environment.

For the first time in my stay at "El Margarita" I did not have to face rejection and loneliness, or the girl with the "bad" teeth being the only one wanting to talk to me. Fewer classmates dared to call me names. Although there were tangible vestiges of past hostility directed at me, I was finally able to navigate school with a more tolerable amount of pressure and knowing there was at least the slightest possibility I would be heard if need be. I was perceived as more connected to the (white) North-Atlantic, than to the (black) local south after all. Decaribbeanization by the means of migration had granted my blackness a pass for acceptability.

During the second year I shared the classroom with approximately thirty-five other girls. As in first grade, I was an absolute token. The other black girl in elementary school was in fourth grade and my peers consistently encouraged me not to talk to her because, according to them, there was no reason for me, a (now)"nice brown girl" to befriend someone like her, that is to say, someone that, unlike me for some reason, they labeled "a black and ugly one", "an ugly negra". I was certainly better placed socially than before my trip to the first world, but race continued to drive my hyper visibility. Moreover, racism continued to be a very present issue in the academic context. After being called out and reprimanded on their acts of discrimination but, most importantly, after realizing I had a family that supported me and that could even take me abroad if they wanted to, the school community decided to make concessions as to how to treat me. I was still black, and their racist gaze still highlighted me as such, nonetheless.

\section{The fascinating story of Giovanny, or how queerness and unsacramentality cancel physical whiteness.}

On the other hand, I remember not being the only hyper visible child on campus. One of my classmates, Giovanni, seemed to be in the spotlight as well. I would not say the light shining upon us was the same hue or intensity, but it is for sure that Giovanni's presence was highlighted in a specific way. She had a hoarse (manly?) voice, a lisp, natural iceblonde-long-straight hair, bright blue eyes, and a masculine name. We were not particularly close, but I do not remember holding any kind of negative feelings towards her either. I always found her sort of rough and weird but that was all. 
I think for me, as for the rest of the class (and perhaps the whole school), she was enigmatic in some kind of way. She was outgoing and active, and also a great student. I do not remember her as especially impoverished, and never heard her tell any sad story about her family, which was often the case amongst other girls. What I do have are memories of nuns staring at her during the break, while we were all playing, and commenting on how pretty that $m o n a^{5}$ was.

Despite being probably the only student at school who resembled Jesus and the Virgin Mary-as depicted in religious imagery - there was some sort of demonic halo surrounding her. It did not stem from her behavior or physical traits, but rather from the queer conjunction of her rough voice, her little speech impairment, and the fact that everybody knew she had not been baptized yet (I had not either but that was a secret). In fact, nuns and teachers would often point out that her masculine name would (should?) be changed into the right, feminine version of it: Giovanna, by the means of, during, or as a result of baptism. I wonder if they were expecting this ' $a$ ' at the end of her corrected name would also fix her tendency to physical aggressiveness and "unfeminine" expressions. That aside, no one seemed to be concerned about her piousness or condemnation because she was as devoted as anyone else.

\section{Better (maybe) than the real mona, the cosmic one: Myriam, white by default, baptism, or normative femininity}

Other monas like Myriam, also from our cohort, would be in a more coveted position than Giovanni, despite her darker whiteness. Like Giovanni, Myriam was always amongst the top students, was raised in a stable household, and her manners were well regarded by adults in the community. I guess she also kept good relationships with her classmates, and was not problematic at all. She was not "at risk", she was not in need. Brown-eyed and not as fair-skinned as Giovanni, but a nice monita, anyway. Not black. Not indiecita. This is important.

In Latin-American societies, anti-blackness and anti-indigenism exist along with the imaginary of a so called "cosmic race". This race, according to Mexican intellectual José Vasconcelos, resulted of the melting of the "main human races" ("white", "red", "yellow", and "black") and, most importantly, was meant to dethrone the Europeans. Furthermore, Vasconcelos asserted that the civilization achieved by the white colonizers "established the material and spiritual bases for the union of all men in a fifth race, a universal race that is the fruit of all earlier races and surmounts all that is past" (Vasconcelos, 2011). Reflecting on the possible challenges of race mixing in a race-segregated world, he adds that

"Many obstacles stand in the way of the plan of the spirit, but they are obstacles that progress always faces. An immediate objection might be to ask how the different races will join in harmony when not even the children of a single stock can live in peace and joy within the economic and social system that now oppresses mankind. But this state of mind will have to change quickly. All the trends of the future are currently interrelated: Mendelism in biology, socialism in government, a growing openness in souls, general progress, and the appearance of the fifth race that will fill the planet with the triumphs of the first truly universal, truly cosmic culture" (Vasconcelos, 2011).

In Vasconcelos' logic, Myriam was more suited to reign than Giovanni, for obvious reasons: she was a visible member of the cosmic, more universal, more complete race. Also, in the plan of the spirit, her proved adherence to gender norms and sacramental life gave her an unchallenged advantage. She was at the most privileged intersection of race, class, gender, and sexuality within our context. Her face was worthy of representing a school, a neighborhood, a nation so fervently aspiring to "truly" cosmic whiteness, "universal" urban, middle class life-style, heteronormative femininity, and perfect Catholic devotion. She filled our micro-world with the triumphs Giovanni should have had. I had them, in fact, but they were unfairly colored with my blackness.

\section{“(...) we are not whites of pure race, but we will never stand to be governed by Blacks."}

Besides being the only black girl in second grade, and coming from a more stable family background, I was also an outstanding student. In spite of eventual resistance from other girls, I would usually be selected to perform as an actress, dancer, or speaker at special events, as it was the case for the closure performance of second grade. The event took place in the theatre-chapel, where every important assembly was held. My teacher had chosen me as the official MC to host the whole ceremony, and I was both honored and excited. It was not the first time I had been chosen for a ceremony, but this one felt like the most important ever.

Mona: originally meaning female chimp, this world is used in Colombia as a synonym for White, whiter, blonde, or red haired interchangeably. Girls like Giovanni would be considered a more genuine type of mona, because of her pale complexion and light blue eyes.

6 Bunaventura Báez, president of the Dominican Republic between 1849 and 1878, quoted by Mu-Kien A. Sang in Buenaventura Báez, el Caudillo del Sur (1844-1878). Original text in Spanish: “(...) no somos blancos de pura raza, pero jamás soportaremos ser gobernados por negros." 
I was almost done getting ready for the big day when a teacher from another section called me on the phone. Not my mom but me directly. Although I took the call not knowing exactly what to expect, I was not ready to hear what she said either. It took me completely off guard. Out of the sudden, she had decided that Myriam would take my place as the MC. "I know you wanted this but that mona is so cute," she said. I guess Myriam was not pure white but at some point, someone with authority over me would impede me from reigning.

I do not remember what I replied or if I ever replied at all. After I hung up, I stayed sitting on my mother's bed, holding the nice white satin ribbon barrette she had bought for me to wear for the closing. She tried to comfort me but that was hard to do without an explanation for what has just happened. I guess I finally got over it because I always won awards and distinctions at that school regardless. The year before, for instance, I was crowned Queen of the Multiplication Tables, after beating everybody in a fierce competition. Giovanni was the first runner up and Myriam did not even make it to the final.

\section{¿Blanquidad de la falsa o de la legítima? ${ }^{7}$ : mestizaje and blanqueaminto in Latin American modern nations}

As a result of European colonization and, more precisely, as a vestige of the caste systems implemented by Spain and Portugal, Latin American national projects have historically involved blanqueamiento (whitening and whitewashing) as the main vector for progress. In former Latin colonies,

"societies were organized in a rigid, racially determined, caste system. The upper two castes included whites only. Below these two came the castes formed by individuals of mixed European and Indigenous ancestry, the Mestizos. Next in the pecking order were those of mixed European and Africa ancestry, the Mulattos. In the lowest castes were the indigenous and the blacks. From the perspective of whites, this hierarchy was more than a mere expression of colonial power. It was also an expression of the natural order regarding intelligence and beauty among the races" (Iyer \& Martínez, 2008).

The peculiarity of his social order resides in the fact that the relegation of blackness to the lowest cast endorses the idea of whiteness as the ultimate aspirational value while simultaneously establishing mestizaje (race mixing) as the strategic dispositive to it. As opposed to the segregation model imposed by the British in their colonies in North America, former Iberian colonies instituted miscegenation in order to breed the black and indigenous components out of the national blood. In our modern societies, mestizaje is at the core of imagined homogeneous, neutral, racially democratic republics, that paradoxically envision it by means of blanqueamiento (genetic whitening through racemixing, and cultural oblivion by symbolic white-washing).

On the other hand, the caste system implied oblivion as a mechanism of whitening. The expression "we all have a lost indigenous grand-mother and we should not look for her" is very often used by white-mestizo mothers that fear their children will indigenize or blacken their lineages back, by espousing women of darker complexions, or more salient indigenous phenotypical traits. In fact, structural ideology of mestizaje-blanqueamiento has complicated racial selfrecognition amongst Latin-American populations. Colombian Census of 2005 reveals that only $10 \%$ of the population identify as Black. Because, since colonization many Latin Americans rarely hace have neither information, or any sort of awareness of blackness and indigeneity in their genealogy, they will identify as mestizo/mestiza (as in "cosmic?"), moreno/morena (brown), and even white, which will continue to distort demographic representation in terms of race and ethnicity in every country in the region.

\section{Mestiza and mestizo as ideal national subjects}

In Latin America and the Caribbean, mestizaje (race mixture) and blanqueamiento (racial whitening and cultural whitewashing) are inevitably intertwined. Race mixture or mestizaje are inextricable from the ancient system of castes, and therefore do not and cannot neutrally signify the mixing of races. The goal of mestizaje is to produce a whiter homogenized national identity that successfully leaves behind-and conceals- every trace of Blackness or indigenousness.

Vasconcelo's idea of the "cosmic race" is actually a fantasized reformulation of the concept of mestizaje that clearly responds to a whitening/modernizing/decaribbeanizing project, since it is conceived as "procreated by the development of international sexual relations, and impregnated with modern communications" (Tardieu, 2015). Mexican sociologist Mónica Moreno Figueroa states that mestiza:

$$
\text { “(...)is) a) racial) category) that) emerges) as) a) key) component) of) the ideological myth) of) formation) of) the) }
$$

English translation: Blanqueamiento (whitening and white-washing) and mestizaje ( race mixing): real whiteness or fake whiteness? The question was asked by an acquaintance of mine, during a colloquial conversation on race issues. 
Mexican) nation, namely) mestizaje, during) the) late) nineteenth) and) early twentieth) centuries.) In) such) a) project) of) state) formation, ) Mexican) is) equivalent) to) Mestiza.) Mestiza) refers) to) those who represent Mexicanness and, therefore those) who) are) closer) to) the) model) of) the) ideal) subjects) of the) Mexican) Mestiza) nation" (Moreno Figueroa, 2011).

This argument is also valid for Colombia, where most people identify as mestizo or mestiza, categories that name the racially unmarked -and is reminiscent of Vasconcelo's cosmic race-rather than the white. Turning back to the story, Myriam's whiteness is closer to the representation of an ideal Colombian girl (mestiza) than Giovanni and I. The lightskin mixed, racially untraceable subject is idealized in Colombian socio-historic context.

As former president of the Dominican Republic Buenaventura Báez expressed it: "mestizos are not "whites of pure race' but In Latin American and Caribbean nations, they emulate the role of "pure whites" that govern North-Atlantic nations and that colonized what is now American soil. As stated above, blanqueamiento in Latin American nations mobilizes images and projects of progress and represents the ideals of national identities. Phenotypical, cultural, and political whiteness is supposed to be achieved through race mixing (therefore White immigration was fostered), but also through hygiene programs, emulation of European mores, adherence to Catholicism, and whitewashing of emblematic images, such as the portrait of Juan José Nieto Gil, the only Black president in the history of Colombia” (Guillén, 2013)

Anthropologist Peter Wade asserts that in a mestizaje-blanqueamiento ideological system, miscegenation and discrimination coexist. As opposed to what happened in the United States, races were not meant to remain strictly separated but rather they would mix as a means to breed the non-white out of collective blood. Simultaneously, segregation remains necessary to perpetuate the myth of white superiority.

Races are not to mix out of love or altruism, but for political interests. That explains why, even if almost everyone identifies as mestizo, Black and indigenous populations remain economically, culturally, politically and geographically marginalized. In this sense, blanqueamiento is hegemonic (Wade, 1991).

\section{Travel bans are not exclusive to Trump's America}

In an effort to ensure that the racial composition of their populations was not jeopardized by international migrations, Colombia, the Dominican Republic, Costa Rica, and Venezuela Colombia instituted legal bans on people of Chinese and African descent (Hernández, 2012). All of these countries also propitiated the arrival of Europeans, with the aim of fostering international sexual relations that were expected to result in the improving of their national mestiza races. In the Second Conference on Race, during 1920 in Bogotá, Minister of Education Luis López de Mesa openly stated that European migration would be the solution to the supposedly overwhelming backwardness of the nation. According to López de Mesa, people's evolution towards civilization was naturally too slow and would not respond solely to education and hygiene. Therefore it should be accelerated by means of white European immigration (Navia Hoyos, 2014) .

In a country that went these lengths in its quest for whiteness, the persecution displacement and, ultimately, negation of blackness is an obvious outcome of a national project that is deeply rooted in colonial governance, and profoundly dominated by Catholicism. This also explains my experience of becoming a negra permitida ${ }^{8}$ after my trip to the land of Mickey Mouse.

\section{Conclusion : Whiteness as a Machinery of oblivion': artifice of the void}

While writing my personal story I vividly rekindled the experience of emptiness that I felt in my everyday reality at school and could not avoid to ask myself if whiteness as I know it needs my emptiness to exist. Does whiteness depend on (my) void?

I recently conducted a brief digital ethnographic experiment on my Facebook wall, which consisted basically in interrogating people on their racial identification. I made a post with the question " ¿Cómo se identifican ustedes racialmente?" (How do you self-identify racially speaking?). Although the aforementioned post was open and public, writing it in Spanish and with no ethnic restrictions, I knew I was targeting Spanish-speaking, non-black people.

I thought the silence, the many times declared inability to respond to this question, the many expressions of confusion it aroused, the evident fear or shock at the mere invitation to tackle the subject, as well as the mentions of

8 English translation: admissible black girl. I borrow the notion from Colombian scholar Diana Carolina Sierra Becerra, who uses it to explain the situation of the first Black Miss Colombia, Vanessa Alexandra Mendoza, crowned in 2001 in the midst of a controversy (Sierra Becerra, 2017).

9 I borrow the notion from Nigerian Historian Abosede Ajibike George (George, 2014). 
ignorance and oblivion regarding their family roots somehow mirror a particular dimension of my subjective experience in the first year at Margarita Bosco. From a completely different place (that of an adult, informed researcher), I relived emptiness and alienation while reading the thread.

Of the 44 people that took part in the forum, 40 were evidently undecided about their race. Some identified as mestizo or mestiza. One of them explained this identity as inevitably linked to being in ignorance regarding their family origins. Someone else said she was scared to identify herself racially altogether. Many felt the need to draw on history, sociology and anthropology to theorize on their racial identification. Some others took the time to explain why they did not 'feel' white, or identify with the idea of being white, in spite of being classified as such by society and also enjoying the privileges attached to it. The only subjects who responded plainly and shortly were those clearly racialized by Black, both in our context and transnationally.

My assertion that the emptiness I felt while reading the answers to my question mirrors the one I experienced at school as a child goes beyond an intent to compare them. In point of fact, I state that emptiness and confusion they expressed is what was projected onto my young humanity. I wonder if the many episodes of migraine and emesis all over campus were not vivid enactments of my urge to empty myself from both, the pain inflicted by racist hate, and a whole inner world that had introjected whiteness as the reigning denial of my own black self.

The void that was casted upon my individual being is embedded in a historical continuum of epistemic erasure and physical murder. Moreover, I am tempted to think that the possibility for whiteness to exist in our context is the material and symbolic disowning, displacement, dispossession, and dehumanization of blackness and the ones who inhabit it, especially if they are female. In this regard, Portuguese artist and scholar Grada Kilomba points out that

"in a gender-race schema(...) Black women [and especially girls] ${ }^{10}$ come to occupy a very difficult position within the white supremacist patriarchal society. We represent a kind of a double lack a double Otherness as we are antithesis of both whiteness and masculinity. In this schema, black woman can only be the 'Other', never the self' (Kilomba, 2010).

Kilomba goes further to assert that the intersection of misogyny and racism dis-locates Black women and girls in the position of Other of the Otherness, inevitably inseparable from symbolic and material death. The author adds that

"In this context of absolute isolation, suicide among black women can be seen as the perfection of their existence as Óther of Others (...) in the sense that suicide is the 'perfect' portrayal of disqualified self, a self that has no Other of its own - a faultless act of non-existence" (Kilomba, 2010).

Can whiteness exist without a project to annihilate us?

\section{References}

Alcaldía Mayor de Bogotá. (2005). Población afrocolombiana en Bogotá: línea de base. Retrieved from www.sdp.gov.co: http://www.sdp.gov.co/sites/default/files/2011_linea_base_bta.pdf

Aleteia. (2019). www.aleteia.org. Retrieved from https://aleteia.org/slideshow/slideshow-top-ten-most-catholiccountries/6/

Arias, R. (2000). Estado laico y catolicismo integral en Colombia: la reforma religiosa de López Pumarejo. Uniandes Historia Crítica No. 19, 69-96.

Bassi, E. (2016). An Aqueous Territory:Sailor Geographies and New Granada's Transimperial Greater Caribbean World. Durham: Duke University press.

Colegio Margarita Bosco. (2019). www.colegiomargaritab.com. Retrieved from http://www.colegiomargaritab.com/ quienes-somos/

Corte Suprema de Justicia de Colombia. (1973). Concordato entre la República de Colombia y la Santa Sede. Retrieved from http://www.cortesuprema.gov.co/corte/wp-content/uploads/subpage/exequatur/Instrumentos\%20 Internacionales/CONCORDATO\%20ENTRE\%20LA\%20REPUBLICA\%20DE\% 20COLOMBIA $\% 20$ Y\%20LA\%20SANTA\%20SEDE.pdf

George, A. (2014). Making Modern Girls: A History of Girlhood, Labor, and Social Development in Colonial Lagos. Ohio: Ohio University Press.

11 Square brackets added by me. 
Guillén, G. (2013). Did Colombia Whitewash the legacy of its Only Black President? www.thecitypaperbogota.com.

Gutiérrez, J. (1994). eltiempo.com. Retrieved from https://www.eltiempo.com/archivo/documento/MAM-189128

Helg, A. (1987). La educación en Colombia, 1918-1957: una historia social, económica y política. Bogotá: Universidad Pedagógica Nacional.

Hernández, T.K. (2012). Racial Subordination in Latin America: The Role of the State, Customary Law, and the New Civil Rights Response. Cambridge University Press.

Iyer, V. and Martínez, R. (2008). Latin America’s Racial Caste System: Salient Marketing Implications. International Business and Economics Research Journal, 55-62.

Kilomba, G. (2010). Plantation Memories: Episodes of everyday Racism. Münster: Unrast.

Moreno Figueroa, M. (2011). Naming Ourselves: Recongnizing Racism and Mestizaje in México. In J. MacLaughlin, P. Phillimore, \& D. Richardson, Contesting Rcongnitions (pp. 122-143). Basingstoke: Palgrave.

Navia Hoyos, M. (2014). Emigrar para vivir, servir para inmigrar: Legislaciones para las inmigraciones de judíos a América y Colombia entre 1880 y 1930*/Emigrate to live, Serve to Immigrate. American and Colombian Immigration Legislation for Jews between 1880 and 1930. Revista Coherencia, 253-269.

Rosero-Labbé, C.M. (1998). Mosquera, Claudia. 1998. “Acá antes no se veían negros”: Estrategias de inserción de migrantes del Pacífico colombiano en Bogotá, Bogotá. Observatorio de Cultura Urbana lDCT. Bogotá: Observatorio de Cultura Urbana IDCT.

Santiesteban Mosquera, N. (2017). El color del espejo: narrativas de vida de mujeres negras en Bogotá. Cali: Icesi.

Sierra Becerra, D.C. (2017). The First Miss Colombia and the Limits of Multiculturalism. Latin American and Caribbean Ethnic Studies. 12(1), 71-90.

Tardieu, J.P. (2015). El negro y la raza cósmica de José Vasconcelos. Boletín Americanista No. 71, 155-159.

Vasconcelos, J. (2011). Mestizaje. In I. Stavans, José Vasconcelos: the Prophet of a Race (45-90). Piscataway: Rutgers Univeersity Press.

Wade, P. (1991). The Language of Race, Place and Nation in Colombia. Ed. Alacrán, 1991. Alacrán.

World Bank. (2005). The Gap Matters, Poverty and Well-Being of Afro-Colombians and Indigenous Peoples.

Cite this article as: N atalia Santiesteban-M osquera (2021). Sketching Whiteness in a M estizo Nation. International Journal of A frican Studies. 1(3), 31-40. doi: 10.51483/ IJAFRS.1.3.2021.31-40. 